\title{
Calling for a reappraisal of the impact of quinoa expansion on agricultural sustainability in the Andean highlands
}

\section{Llamado a una revaluación del impacto de la expansión del cultivo de quinua sobre la sostenibilidad agrícola en el altiplano andino}

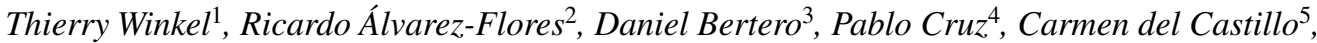 \\ Richard Joffre ${ }^{2}$, Santiago Peredo Parada ${ }^{6}$, Luis Sáez Tonacca ${ }^{6}$
}

\begin{abstract}
The debate on the environmental and social sustentainability of quinoa in its area of major world production (southern highlands of Bolivia) revived with the acceptance by the United Nations of the Bolivian proposal to declare in 2013 as the Year of the Quinoa. Public debate focused on local impacts of quinoa expansion in the Southern highlands of Bolivia, denouncing several negative impacts of quinoa culture such as land degradation, socioeconomic disrupts and biodiversity loss.

However, the global or at least the international implications of the expanding quinoa market were less debated and often in caricature, varying between culpability and ingenuity among consumers, while Andean producers were described as trapped by poverty or short sighted greed. If researchers are to make a relevant contribution to the debate on the impact of quinoa expansion on the social and environmental sustainability of the Andean agriculture, is it necessary to re-evaluate present knowledge and ignorance about local Andean production systems integrated with links at the global scales, taking into account local- global interactions. In the present paper are revisited some major ill-founded assertions commonly expressed in this debate and three lines of arguments are used to support the need for a more cautious and ethical approach to quinoa related issues.
\end{abstract}

Key words: debate, biodiversity, socioecological.

\section{RESUMEN}

El debate sobre la sustentabilidad ambiental y social de la quínoa en el área de mayor producción en el mundo (tierras Andinas del sur de Bolivia) revivió con la aceptación por las Naciones Unidas de la propuesta de Bolivia de declarar el año 2013 como el Año Internacional de la Quínoa. El debate público se focalizó en los impactos locales de la expansión de la quínoa en las tierras Andinas del sur de Bolivia, denunciando diversos impactos negativos del cultivo de la quínoa tales como la degradación del suelo, conflictos socioeconómicos y pérdida de biodiversidad.

Sin embargo, las implicancias internacionales o globales de la expansión del mercado de la quínoa fue menos debatido y a menudo cariturizado, fluctuando entre culpabilidad e ingenuidad entre consumidores en tanto que productores Andinos eran descritos como atrapados por la pobreza o una avaricia miope.

Si los investigadores han de hacer un aporte relevante al debate del impacto de la expansión de la quínoa sobre la sustentabilidad social y ambiental de la agricultura Andina, entonces es necesario reevaluar el conocimiento e ignorancia actual sobre los sistemas de producción andina en forma integrada con escalas globales, teniendo presente las interacciones locales- globales. En el presente estudio son revisadas algunas aseveraciones desafortunadas más importantes expresadas en este debate utilizando tras clases de argumentos para fundamentar la necesidad de un enfoque más cauto y ético en los problemas relacionados con la quínoa.

Palabras clave: debate, biodiversidad, socioecológico.

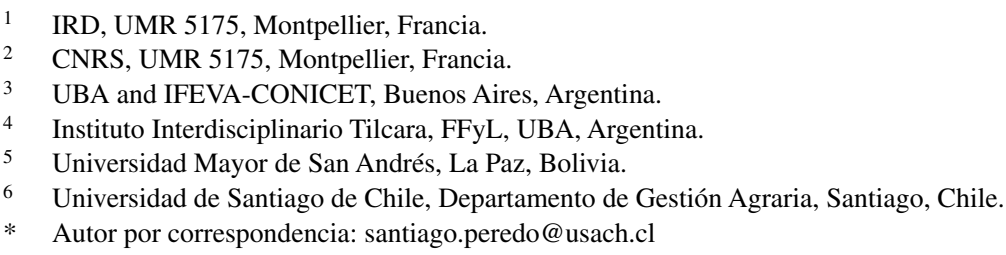

Fecha de Recepción: 26 Julio, 2014.

Fecha de Aceptación: 7 Octubre, 2014. 


\section{Preamble}

Accepting a proposal of the Bolivian government, the United Nations declared 2013 as the International Year of Quinoa (IYQ-2013), shedding light on a crop species well-known in its ancestral Andean lands, but up to now marginal in the rest of the world. This initiative re-ignited the debate opened some years before on the environmental and social sustainability of quinoa in its area of major world production, namely the southern highlands of Bolivia (Rojas et al., 2004; Hellin \& Higman, 2005; Laguna, 2011). In most public media the debate focused on the local impacts of quinoa expansion in this region, denouncing land degradation, socioeconomic disruptions and, less frequently, biodiversity losses (e.g Romero \& Shahriari, 2011; Sherwin, 2011). However, these assertions frequently used rough approximations and stereotypes about these remote lands and societies. However, the global-or at least international-implications of the expanding quinoa market were less debated and most often in caricature, oscillating between culpability and ingenuity among the consumers in quinoa importing countries, while Andean producers were described as trapped by helpless poverty or short-sighted cupidity.

Recently published scientific papers add to these debates, warning against the pressure stemming from the agricultural intensification in the fragile Andean highlands (Jacobsen, 2011; Bazile, 2014), their wild biodiversity (Small, 2013, 2014), up to and including the equity and cultural identity of their local societies (Jacobsen, 2011; Ruiz et al., 2013).

If we researchers are to make a relevant contribution to the debate on the impact of quinoa expansion on the social and environmental sustainability of the Andean agriculture, we should re-evaluate our knowledge (and our ignorance as well) about local Andean production systems, without disconnecting them from their links at the global scale. Indeed, food trade exchanges, seed property rights, food certification and, last but not least, producer-consumer relationships all imply local-global interactions that have direct impacts on local socioecological systems and should be considered in the most objective and transparent way, without eluding any questions.

Here we revisit some major ill-founded assertions commonly expressed in this debate and use three lines of arguments to support our claim for a more cautious and ethical approach to quinoa-related issues.
We thus discuss: (1) the spreading of erroneous statements based on unsupported affirmations or clichés, (2) the pitfalls of anachronisms and generalizations based on fragmentary or local evidence, (3) the need for a more ethical reflection on scientific research in quinoa production in the Andean area and its worldwide extension. We believe that pointing out these ill-founded assertions will help to define a number of social and environmental issues awaiting research efforts on the quinoa crop system, its environmental impacts and its potential as a sustainable and equitable farming system.

\section{Cliches and unsupported affirmations}

Assertions stemming from cliches or mere fantasy are common on internet blogs, but they are also pervading scientific publications. When researchers propagate erroneous beliefs and amplify the internet buzz, they do so with a particular responsibility, since they confer a usurped scientific authority to unsupported and frequently sensationalist affirmations. An example is found in Small (2014) who writes without citations to sustain it: "Despite having their hands cut off or even being killed for growing the grain, the Incas managed to maintain their interest in Quinoa in hidden locations." Such abuses against quinoa producers are not corroborated by historical chronicles, not even by the defenders of the Native American people such as Las Casas or Guaman Poma de Ayala. To our knowledge, there is no colonial source that depreciates quinoa. On the contrary, Diez de Betanzos (1551) and Cieza de León (1553) underlined the importance of quinoa for the food security of the local populations in the cold areas of the Altiplano, in particular for the mine workers.

Other views refer, although with contradictory implications, to the management of biodiversity by Andean farmers. On one side, some authors are alerting to the attacks that cultivated and wild biodiversity would be suffering due to the expansion of the quinoa crop (e.g. Jacobsen, 2012; Small, 2013; Bazile, 2014). These alerts are based on what is generally observed in similar situations around the world, but the authors could not make these similitudes explicit or refer to any relevant study in the Andean region. As regards quinoa in particular, at least two studies suggest that the booming commercial production in the southern highlands of Bolivia has not altered 
its biodiversity, measured either by molecular markers (Del Castillo et al., 2007) or based on field inventories of quinoa landraces presently cultivated (Bonifacio et al., 2012).

On the other side, some experts highlight the integral management of their agroecosystem by the Andean peasant farmers, an example of which being that they maintain a diversity of wild quinoa relatives within the agricultural space (Bazile, 2014). The word "maintain" suggests a deliberate practice on the part of these farmers, while in reality there is no evidence of such a voluntary activity. Thus until we get more data, the presence of wild relative species near or within quinoa fields should be considered simply as the unintentional result of the local crop system. Hence it seems also overstated to sustain that the management of the biodiversity by Andean farmers breaks away from the Western cultural model where agriculture and nature are separated (ibid.)

Land use is another issue of the debate in the boom of the quinoa production in the Andean region. In this respect, it seems hardly credible that: "In Peru and Bolivia, production today is in fact the same as that achieved in the 1960s prior to intensification" (Bazile, 2014). On a land area as well as on a grain volume base, quinoa production in Bolivia shows an increase dating back to the 1970s (Laguna, 2011; Walsh-Dilley, 2013). Compiling national statistics from the FAO database (www.faostat.fao.org/) Rojas (2011) showed a doubling of the areas under quinoa cultivation in Peru and Bolivia between 1970 and 2009. Using the same database, we found quinoa production in 2012 higher by a factor of 2.8 in Bolivia and 1.8 in Peru in comparison to the maximum levels of the 1960-1970 decade. It should be mentioned here that in the southern highlands of Bolivia quinoa did not encroach on native habitats as mentioned by Jacobsen (2011) and Small (2013) but on agricultural pastures whose floristic composition has been modified by llama and sheep herding for centuries. Thus quinoa expansion in these highlands is not a case of an expanding agricultural frontier but rather a process of land use change within the agricultural space.

Finally, and without discussing the simplistic dichotomies inherited from a conventional rhetoric such as modern/traditional, capitalist/peasant, indigenous/Western (Walsh-Dilley, 2013), these views about the management of biodiversity and land use by Andean farmers have more to do with mental routine than with any sound reality.

\section{Generalizations and anachronisms}

A lack of perspective on the recent history of Andean countries is a cause of much misleading reasoning, mixing causes and consequences of quinoa expansion. A common assertion in this respect claims that, in Bolivia in particular, the elevated price of quinoa exports would have skewed the traditional local consumption towards export to wealthy countries in the Northern Hemisphere (United States, Canada, Europe, etc.), supposedly depriving local populations of an invaluable food resource (Jacobsen, 2011; Small, 2013). This assertion is not only wrong because it ignores the processes of massive food donation and food westernization dating back to the 1960s, long before the quinoa boom (Laguna, 2011; Winkel et al., 2012; Kerssen, 2013), it also conveys a connotation of culpability supposed to weigh upon consumers of Andean quinoa in the importing countries. This might result in an ill-advised reaction of giving up these importations while promoting a new "local" quinoa production in northern countries. For the economy and the image of Andean quinoa farms, the consequences of such a wrong appreciation could be quite detrimental. Consumers and decision makers in importing countries should be conscious that Andean peasant farmers are not just "guardians" of an ancestral folklore including the wealthy biodiversity of their native crop landraces (Ruiz et al., 2013). This simplistic concept of conservation of the agro-biodiversity cannot inspire a sustainable and economically viable agriculture. The Andean quinoa producers have the right to access and take advantage of the international food market. Some people would argue here that farmers choosing to export quinoa should then also accept the common rules of international capitalism and free market. A counterargument is that if it intends to be viable and ethical, international food economics should not be reduced to the mere rule of the fox in the henhouse; as indicated by De Schutter (2011), some regulation has to be established to avoid a situation of unfair competition between agroindustry and small farmers (this ethical argument will be discussed in the last section).

This raises a point of criticism of the IYQ-2013 initiative which, while promoting the worldwide diffusion of quinoa and recognizing the fundamental contribution of Andean farmers to its wealthy agrobiodiversity, did not go far enough in exploring the 
concrete legal and economic conditions necessary for the fair attainment of these objectives. Meanwhile, what is emerging today is the intermediation of seed companies selling registered quinoa cultivars in northern countries. In Europe, high-technology breeding research has released three registered quinoa varieties up to now, of which only one ("Pasto" COV EU 19049) is being cultivated on a commercial scale in France, mostly under a nonorganic and highly mechanized farming system. This "healthy diversity" of the European quinoa praised by seed companies must compared with the 50-landrace biodiversity managed by quinoa producers in southern Bolivia (Bonifacio et al., 2012), mostly under an organic and only partly mechanized cropping system.

\section{Ethics for quinoa production and cooperative research}

According to the resolution of the United Nations (FAO, 2011), the purpose of the IYQ2013 was essentially twofold: (i) to recognize "that Andean indigenous peoples, through their traditional knowledge and practices of living well in harmony with mother earth and nature, have maintained, controlled, protected and preserved quinoa in its natural state, including its many varieties and landraces, as food for present and future generations", (ii) "to focus world attention on the role that quinoa biodiversity plays, owing to the nutritional value of quinoa, in providing food security and nutrition", in support of the international agreements on poverty eradication and Millenium Development Goals.

As mentioned above, the IYQ-2013 did not tackle the concrete aspects of the worldwide diffusion of quinoa: commercial interests, seed property rights and unbalanced competition between farmers from southern and northern countries remained poorly debated among experts and local stakeholders. As regards commercial competition, it seems ethically unacceptable that after four decades of hard work with limited public assistance, Bolivian peasants, having built a prosperous international market for quinoa, now enter in direct competition with agriculture from Europe and Northern America, these latter starting up with the support of powerful agribusiness systems praising a "challenging new local production". Capturing a growing part of the market essentially built by Andean small farmers, these farmers from the Northern Hemisphere also compete directly with the commercial quinoa production recently emerging in other Andean countries such as Argentina, Chile, Ecuador and Peru. In France, one of the major quinoa importing countries in Europe, it took only two years for a group of about thirty producers to occupy $10 \%$ of the country's quinoa market. In reality, this "new local production" leeches off the quinoa biodiversity and the niche markets patiently built by small Andean farmers. One should recall that, in the arid and cold highlands that form the areas of major commercial production of quinoa today, peasants do not have any other farming alternative. By contrast, farmers in northern countries benefit from a much more favorable natural and socioeconomic context and have many other commercial options than that of producing quinoa. Thus quinoa growers from northern countries could well be considered as unfair competitors to Andean farmers, unless some compensatory mechanism is concerted and implemented between both parts.

Concerned by possible negative impacts of quinoa cultivation in the Andes, Bazile (2014) asks if "the expansion of Quinoa crop areas outside its original zone [can] serve to reduce the pressure stemming from the intensification of Andean agriculture on the fragile land of the Altiplano, or will it only serve to develop competitive markets?" Contrary to what the author suggests, there is no contradiction here; the promoters of new competitive markets will precisely argue that they are "reducing the pressure stemming from the intensification of Andean agriculture on the fragile land of the Altiplano". However, these negative impacts remain unproven so far (Winkel et al., 2012) and give an example of how mere suppositions, after being propagated as facts by expert sources, are used to promote questionable solutions.

Consciously or not, researchers thus contribute to the propagation of ill-founded arguments regarding quinoa production, denouncing environmental and social disasters in the Andean area and at the same time promoting the development of competing quinoa production in northern countries. Notwithstanding the beneficial effects of foreign technical cooperation in the beginning of commercial quinoa production in the Andes (Banks, 2011; Laguna, 2011; Kerssen 2013), the question is raised of the significance of scientific cooperation for the development of smallholder agriculture there. Up to now the most obvious result of scientific cooperation with northern 
countries has been the transfer of genetic resources from the Andean quinoa biodiversity to North America and Europe. This has led to attempts to patent quinoa hybrids (e.g. Colorado State University in 1997) and also to the successful breeding and diffusion of new quinoa varieties outside of the Andean region. Recently, three saponin-free quinoa varieties selected at the University of Wageningen, The Netherlands, have been transferred to a French seed company with license for Europe, United States and Chile (Harrison-Dunn, 2013). These "acclimated" quinoa varieties are now going to be introduced to other European countries and will compete directly with the production of Andean farmers who freely shared their genetic resources with northern researchers some decades ago but did not receive any benefit in return.

However, Andean farmers are not powerless in the face of these changes; the success of the producers of quinoa in the southern Altiplano of Bolivia exemplifies the capacity of family farmers to take charge of their social and economic development and escape poverty. They achieve this by resorting continuously to collective action and by progressively integrating the ecological dimension of a sustainable agriculture (Vassas \& Vieira Pak, 2010; Walsh-Dilley, 2013). Preserving the biodiversity of their quinoa landraces, maintaining the traditional rules of common land property and at the same time avoiding the pitfalls of the agrotechnology and agrobusiness integration, the Bolivian producers could well be an example for other small farmers in the world, and especially for quinoa producers in the neighboring countries in the Andes.

\section{Acknowledgements}

This study was funded by the collaborative program ECOS-Sud A11B03 "ArcheoQuinoas" between MINCYT (Argentina) and CNRS (France), and by the collaborative program 2012-PCCI 12051 "Desarrollo de una perspectiva socioecológica para un rubro prometedor: la quínoa sostenible en Chile" between CONICYT (Chile) and IRD (France).

\section{Literature Cited}

Banks, E.

2011. Bolivian quinoa questions: production and food security. The Andean Information Network: http://ain-bolivia. org/2011/05/bolivian-quinoa-questions-production-and-foodsecurity/ Consulted: 13/05/2014.

Bazile, D.

2014. Contesting Blossoming Treasures of Biodiversity article 42: 'Quinoa -is the United Nation's featured crop of 2013 bad for biodiversity?'- Quinoa, a model crop to examine the dynamics of biodiversity within agricultural systems. Biodiversity: http://dx.doi.org/10.1080/14888386.2014.88 4469. Consulted: 13/05/2014.

Bonifacio, A.; Aroni, G. and Villca, M.

2012. Catálogo etnobotánico de la quinua real. Cochabamba, Bolivia: Fundación PROINPA, 123 p.

Cieza de León, P.

1553. Crónicas del Perú. Cieza de León, P. 1553. La Crónica del Perú. Bolivia: Archivo y Biblioteca Nacionales. Obra digitalizada, Biblioteca El Dorado [2008], 327 p.

De Schutter, O.

2011. Towards more equitable value chains: alternative business models in support of the right to food. New York, USA: United Nations, $21 \mathrm{p}$.

Del Castillo, C.; Winkel, T.; Mahy, G. and Bizoux, J.P.

2007. Genetic structure of quinoa (Chenopodium quinoa Willd.) from the Bolivian altiplano as revealed by RAPD markers. Genetic Resources and Crop Evolution, 54: 897-905.

Diez de Betanzos, J.

1551. Suma y narración de los Incas. Cap. XXVII. Diez de Betanzos, J. 1551. Suma y narración de los incas. Madrid, España: Ediciones Atlas [1987], 416 p.
FAO

2011. Thirty-seventh session. First report of the resolutions committee. Rome, Italy. http://www.fao.org/docrep/ meeting/022/mb458e.pdf. Consulted: 13/05/2014.

Harrison-Dunn, A.R.

2013. Non-bitter European quinoa offers new routes to market. NUTRAingredients.com: http://www.nutraingredients.com/ Research/Non-bitter-European-quinoa-offers-new-routesto-market. Consulted: 13/05/2014.

Hellin, J. and Higman, S.

2005. Crop diversity and livelihood security in the Andes. Development in Practice, 15: 165-174.

Jacobsen, S.E.

2011. The situation for quinoa and its production in southern Bolivia: from economic success to environmental disaster. Journal of Agronomy and Crop Science, 197: 390-399.

Kerssen, T.

2013. Food sovereignty and the quinoa boom in Bolivia. International Conference "Food Sovereignty: A Critical Dialogue". Yale University, USA. Online: http://www.yale. edu/agrarianstudies/foodsovereignty/pprs/79_Kerssen_2013b. pdf. Consulted: 13/05/2014.

Laguna, $\mathrm{P}$.

2011. Mallas y flujos: acción colectiva, cambio social, quinua y desarrollo regional indígena en los Andes Bolivianos. $\mathrm{PhD}$ Thesis. School of Social Sciences, Wageningen University, The Netherlands. Online: http://edepot.wur.nl/188049. Fecha de consulta: 13/05/2014.

Rojas, W.

2011. Quinoa, an ancient crop to contribute to world food security. Santiago, Chile: FAO, Oficina Regional para America Latina y el Caribe, $55 \mathrm{p}$. 
Rojas, W.; Soto, J.L. and Carrasco, E.

2004. Study on the social, environmental and economic impacts of quinoa promotion in Bolivia. La Paz, Bolivia: PROINPA Foundation, $83 \mathrm{p}$.

Romero, S. and Shahriari, S.

2011. Quinoa's global success creates quandary at home. The New York Times, 19 March 2011. http://www.nytimes. com/2011/03/20/world/americas/20bolivia.html?_r=2\&hp= \&pag\&. Consulted: 13/05/2014.

Ruiz, K.B.; Biondi, S.; Oses, R.; Acuña-Rodríguez, I.S.; Antognoni, F.; Martínez-Mosqueira, E.A.; Coulibaly, A.; Canahua-Murillo, A.; Pinto, M.; Zurita-Silva, A.; Bazile, D.; Jacobsen, S.E. and Molina-Montenegro, M.A.

2013. Quinoa biodiversity and sustainability for food security under climate change. A review. Agronomy for Sustainable Development, 34:349-359.

Sherwin, A.

2011. The food fad that's starving Bolivia. The Independent 22 March 2011. http://www.independent.co.uk/life-style/ food-and-drink/features/the-food-fad-thats-starvingbolivia-2248932.html. Consulted: 13/05/2014.

Small, E.

2013. Quinoa: is the United Nations' featured crop of 2013 bad for biodiversity? Biodiversity 14: 169-179.
Small, E.

2014. A rejoinder to Didier Bazile's Letter to the Editor contesting Blossoming Treasures of Biodiversity article 42. Biodiversity 15: 5-5.

Vassas, A. and Vieira Pak, M.

2010. La production de quinoa dans l'altiplano sud de la Bolivie: entre crises et innovations. In: Coudel E., Devautour H., Soulard C.T., Hubert B. (eds.). ISDA 2010: Innovation and Sustainable Development in Agriculture and Food. Montpellier, France. Online: http://hal.archives-ouvertes.fr/ docs/00/52/19/45/PDF/VASSAS-VIEIRAPAKLa_production. pdf. Consulted: 13/05/2014.

Walsh-Dilley, $\mathrm{M}$.

2013. Negotiating hybridity in highland Bolivia: indigenous moral economy and the expanding market for quinoa. The Journal of Peasant Studies 40: 659-682.

Winkel, T.; Bertero, H.D.; Bommel, P.; Chevarría Lazo, M.; Cortés, G.; Gasselin, P.; Geerts, S.; Joffre, R.; Léger, F.; Martínez Avisa, B.; Rambal, S.; Rivière, G.; Tichit, M.; Tourrand, J.F.; Vassas Toral, A.; Vacher, J.J. and Vieira Pak, M.

2012. The sustainability of quinoa production in southern Bolivia: from misrepresentations to questionable solutions. Journal of Agronomy and Crop Science 198: 314-319. 